\title{
On the Design of Energy Absorbing Crash Buffers for High Speed Roadways
}

\author{
Mohammad Sharif Uddin"1*, Jacob Quintel1,2, Grad Zivkovic ${ }^{2}$ \\ ${ }^{1}$ School of Engineering, University of South Australia, Mawson Lakes, Australia \\ ${ }^{2}$ Automotive Safety Engineering Pty Ltd., Lonsdale, Australia \\ Email: *Mohammad.Uddin@unisa.edu.au
}

Received 22 January 2016; accepted 8 March 2016; published 11 March 2016

Copyright (C) 2016 by authors and Scientific Research Publishing Inc.

This work is licensed under the Creative Commons Attribution International License (CC BY). http://creativecommons.org/licenses/by/4.0/

(c) (i) Open Access

\section{Abstract}

The aim of this paper is to design and analyze cost-effective and high energy absorbing buffer systems for high speed roadways. Unlike conventional crash cushions, the proposed buffer design is based on the assembly of a series of cylindrical hollow tubes (cells) with thorough slots around the cells. The idea is that during the collisions, the kinetic energy of the errant vehicles will be absorbed by the progressive deformation of the cells, hence minimizing damage to the vehicle and allowing a comfortable ride down deceleration of the vehicle's occupants. As the cell was the fundamental unit of the buffer design, three cells with different geometry were studied to understand the underlying deformation of the individual cells. Nonlinear quasi-static tests using three-dimensional (3D) finite element (FE) simulation and experimental techniques were performed to evaluate the deformation and energy absorption capacity of the cells. Simulation results matched closely with experimental ones with relatively small errors. Based on the experimental results of single cells, a number of potential buffer systems were designed for 80 and $100 \mathrm{~km} / \mathrm{h}$ speed roadways. Results indicate that the buffers with larger diameter cells are favorable to be used in high speed zones as they reduce the overall size of buffers and contain less number of cells, while being able to absorb the required amount of impact energy. Consequently, they are found to result in a reduced cost associated with materials and fabrication. All the buffer designs were relatively shorter than commercially available buffers used in roadways. In addition, due to their reduced and compact size, the designed buffers can potentially be used in a space limited and hazardous road environment to reduce the vehicle crash with the fixed objects.

\section{Keywords}

Collisions, Fixed Objects, Crash Buffers, Cylindrical Hollow Cells, Finite Element Method

\footnotetext{
${ }^{*}$ Corresponding author.
} 


\section{Introduction}

Road crashes resulting in severe injuries and deaths are a growing concern across the world. For instance, road crashes in Australia cost about \$15 billion annually, representing approximately 1.4\% of Australia’s gross national product [1]. Among them, a large number of road fatalities occur as a result of collisions with fixed objects on roadways. These collisions, often involving trees and poles, are particularly severe due to the narrow shape and rigidness of such objects. This has been an ongoing problem for a number of years. It has been reported that about 36\% of the fatal road crashes in South Australia from 2000 to 2011 involved collisions with the fixed objects [2]. The problem is similar in other parts of the world. For example, in US, approximately $20 \%$ of motor vehicle crash deaths result from a vehicle leaving the roadway and hitting a fixed object alongside the road, in which, collisions with trees accounting for about $50 \%$ and about $13 \%$ with utility poles [3]. In Germany, this was about 38\% [4]. An example of a collision between a vehicle and a fixed object (Stobie pole) is shown in Figure 1(a), indicating that such collision is capable of causing the lethal and devastating impact into the vehicle structure and the vehicle occupants [5].

While improved vehicle and road design has decreased the overall fatality rate, a similar percentage of people are still being killed or injured in collisions with fixed objects every year [2] [6]. As a result of this, the health care burden and long-term severe personal suffering are becoming a growing concern [7]. Due to stringent regulation on road safety, various safety measures have been taken in the design of vehicles. For instance, along with revolution of air bags as safety cushion, the design of the car frame has considered potential safety aspects including innovative shock absorbing structure and material, which can protect vehicle occupants from potential collisions [8]. In this regard, common considerations are light weight, composite material along with unique geometric shapes and structures and their locations on the car frames, which will be able to absorb maximum impact energy through a progressive deformation pattern at a short period of time [9]-[11]. In addition, energy absorbing structures for ensuring safety of railway vehicles are studied by many researchers who emphasized the importance of safety and the innovation design of material and structure to prevent potential fatalities and damages [12].

While in-car safety measures, often called active safety, are able to withstand the collision impact, hence reducing the risk of injury or death to vehicle occupants, they are not a complete solution for an errant car colliding with roadside narrow objects such as tree or pole. It has been reported that among all collisions, head to head or frontal collision is the most common incidence on roadways, in which, a vehicle collides with other vehicle head to head or a vehicle front hits the fixed objects located on road sides. In the case of head to head crash, the frontal contact of two cars is relatively large and hence the deformation and the scale of damage to the car structure are low. On the other hand, in the case of collision between the car front and the rigid object, the contact between the front of a car and the narrow rigid object is too small, the deformation into the car structure is significantly large; in other words, the total impact energy is absorbed by the car itself rather than the rigid object. It must be noted that the impact is even significantly higher when the car side hits the rigid objects as the side of a car is more vulnerable than the front of the car as the side of a car contains a simple door structure as opposed to the front which houses an engine and other energy absorbing structures [13].

In order to minimize the risk of injury or causality due to collision with fixed objects, passive road safety measures such as road side barriers are employed across the world. The main aim of such a road safety system is to protect vehicle occupants from fixed roadside objects that cannot be removed, relocated or made breakaway [14]. In other words, the objective is to absorb most of the kinetic energy of an errant vehicle in a controlled manner, thus greatly reducing the severity of a crash [15].

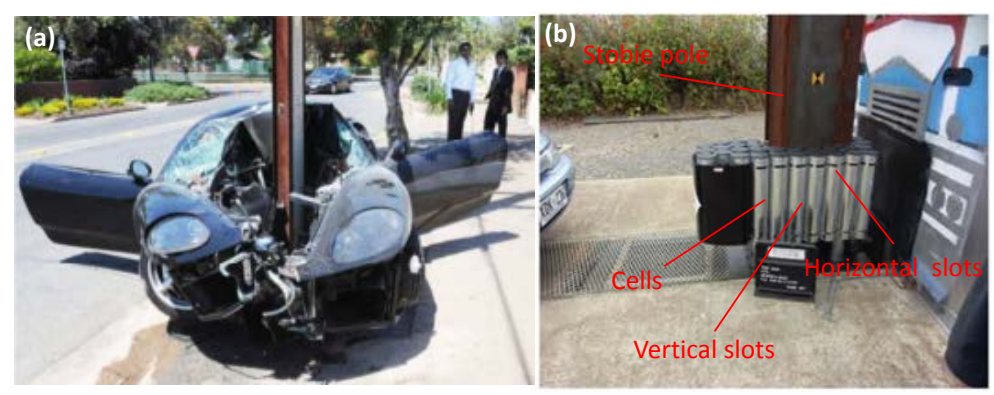

Figure 1. (a) Collision with fixed object (e.g. Stobie pole) [5]; (b) hollow tube based buffer system installed around Stobie pole [29]. 
In addition, as new materials and designs for energy absorbing structures are continually growing and evolving due to the strict regulation of safety aspects to be enforced in both car and road environment, their immediate assessment is crucial to understand the underlying effectiveness and for potential optimization. In this regard, experimental crash tests are often expensive and time consuming [16]. Therefore, finite element analysis, as a powerful computational tool, is a promising means and widely deployed in crash modelling to predict the performance of energy absorption of the safety cushions [17] [18]. In particular, the tool offers tremendous benefits in analyzing new candidate of material and design for extensive parametric studies [19].

This paper aims to design and analyze of a cost effective, compact and high energy absorbing safety buffers, which are capable of absorbing the impact energy of an out of control vehicle in high speed zones of $80 \mathrm{~km} / \mathrm{h}$ and $100 \mathrm{~km} / \mathrm{h}$. The buffer is consisted of a series of metallic hollow tubes (often, called as cells) integrated together and installed around a fixed object. The key idea is most of the kinetic energy of the errant vehicle will be absorbed by the deformation of the individual cells, hence, minimizing impact onto the vehicle structure and protecting vehicle occupants from potential injuries or fatalities. Both finite element and experimental analyses were performed to determine the energy absorbing capability of an individual cell or tube, which led to design the geometric size of a buffer system for high speed zones $(80-100 \mathrm{~km} / \mathrm{h})$. While the design of the cell based buffer system presented in this paper is shown for the frontal impact, the design can be modified into a shape which can be able to accommodate side impacts at any angles (e.g. $45^{\circ}, 90^{\circ}$ ) with respect to the car axis.

\section{Commercial Impact Attenuators}

There are a variety of safety buffers, or often called, impact attenuators, available today for use on the roadside and each of which is designed to absorb the kinetic energy of an out of control vehicle, hence reducing casualties due to collisions [20]-[23]. They vary with the size, shape, and material and are deployed depending on the road environment, hazards, and road speed limit. An extensive review and assessment of a number of safety barriers as an acceptance to use in State of Queensland in Australia is described in [24]. To be noted are Rubber Speed Cushion [25], Universal TAU-II [26], QuadGuard [27], Absorb360 [28]. Rubber Speed Cushion made by the SafeRoads is shown to be an effective energy absorber to withstand the impact resulting from the car colliding with a speed up to $80 \mathrm{~km}$ and typically used in road break ways. However, they are relatively narrow and long and hence are not suitable for placement in front of tree or Stobie pole. Typical length of Rubber Speed Cushion is $5.44 \mathrm{~m}$ for $60 \mathrm{~km} / \mathrm{h}$ and $8.29 \mathrm{~m}$ for $80 \mathrm{~km} / \mathrm{h}$. Universal TAU-II metallic crash cushion designed by ACP has a length of $3.41 \mathrm{~m}$ for $60 \mathrm{~km} / \mathrm{h}, 5.15 \mathrm{~m}$ for $80 \mathrm{~km} / \mathrm{h}, 7.75 \mathrm{~m}$ for $100 \mathrm{~km} / \mathrm{h}$ and $9.48 \mathrm{~m}$ for $110 \mathrm{~km} / \mathrm{h}$. For the given speeds, the designs are significantly shorter in length than Rubber Speed Cushions. However, its complex design and need for a large concrete foundation for installation lead to higher costs. Quad Guard by Boylan is metallic and flexible structure, in which, the cells are compressed under the impact and hence absorbing the collision energy. It has a length of $3.08 \mathrm{~m}$ for $60 \mathrm{~km} / \mathrm{h}$ and $4.91 \mathrm{~m}$ for $80 \mathrm{~km} / \mathrm{h}$ zones. Similar to Universal TAU-II, this crash cushion is an effective energy absorber but still too long in length, costly, and complex for use for individual trees or poles. Absorb360 made by RMS (road management solutions) is a plastic segmented safety buffer and used for frontal impact. It is made with different dimensions and typically has a length of 3.7 $\mathrm{m}$ for $60 \mathrm{~km} / \mathrm{h}$ areas, $6.7 \mathrm{~m}$ for $80 \mathrm{~km} / \mathrm{h}, 9.7 \mathrm{~m}$ for $100 \mathrm{~km} / \mathrm{h}$ and $11.7 \mathrm{~m}$ for $110 \mathrm{~km} / \mathrm{h}$ areas. This crash cushion has a more simple design but it is far too long to be used in many locations and it is not suitable for side impact. Another type of crash cushion used as a road side barrier is water filled plastic barrier fitted with foam [17]. They are generally bulky, heavy and require significant effort to install and maintain depending on the locations of placement. In addition, they may not be environment friendly due to the unexpected leakage or spill of water from the cushion system in the event of collision.

While ideally each of the above safety buffers is, to some extent, effective energy absorbing devices for protection from fixed objects, they are continuous, indiscrete and non-flexible, making them only suitable for open roads. They may not be applied to the closed roads, in which, fixed objects such as trees, poles, commonly exist. Most of them are only designed to withstand the frontal collisions, which may not be the case always in real practice; in other words, they cannot withstand any side impact. Furthermore, due to their complex shape and large size, the fabrication, installation and maintenance cost of these devices is relatively high. Therefore, it is important to design and develop a compact, shorter, flexible, and cheaper safety buffer for road side fixed objects, thus reducing the hazards along the road network and creating a more forgiving roadside environment. 


\section{Energy Absorbing Pole/Tree Buffers}

An important aspect when selecting possible sites for a buffer system is to ensure that the safety system itself doesn't pose a threat to road users, particularly, when the protecting system is located much closer to traffic than the fixed object. Therefore, a key principal in eliminating hazards posed to vehicles by fixed objects is, developing an effective process to identify objects in high-crash locations and an effective set of criteria to select the best option to deal with these objects [14]. Design of such buffer system must ensure that, in the event of a collision, no debris from the system or the vehicle causes a hazard to other vehicles. Energy absorbing pole/tree buffer is first introduced by [29], in which, the buffer contains a series of cylindrical hollow tubes assembled together by the bolt-nut fasteners. The configuration of a buffer fixed with a Stobie pole is shown in Figure 1(b). Each cell contains vertical and horizontal slots at the top and bottom. Vertical slots allow more flexibility within the cells to deform. Horizontal cells are to accommodate the bolts and nuts that fix the cells together. The buffer systems are attached to the fixed objects on the streets. The cells can be arranged in a variety of ways depending on the fixed objects on the roadways.

The current buffer design [29] as described earlier is only suitable for low-to-medium speed zone, e.g. 60 $\mathrm{km} / \mathrm{h}$, and this has been tested successfully. However, they may not be applied in high speed zones, e.g. $80 \mathrm{~km} / \mathrm{h}$ or $100 \mathrm{~km} / \mathrm{h}$. Under such high speeds, the impact of an errant vehicle against a fixed object is expected to be significantly high, and the buffer system needs to absorb a large amount of impact energy to eliminate potential injury to the vehicle's occupants. Hence, a design modification is urgently required to develop an improved, sustained, compact and cost effective buffer that will be suited to faster speed zones and this is of particular interest and the focus of the current paper.

\section{Rationale for Buffer Design for High Speed Zones}

Design of a buffer system involves a number of important geometric parameters. They include length, width, cell geometry (e.g. diameter, thickness). Generally, at the impact, the energy is absorbed through the elastoplastic deformation of each individual cell within the buffer system. Given that the total amount of impact energy to be absorbed at a certain stopping distance is known, it is possible to determine the size of the buffer system by modifying important geometric parameters of the individual cells.

After the impact, the stopping distance of the vehicle is crucial to determine how quickly or smoothly the vehicle comes to rest position without posing any threat to the occupants. The larger the stopping distance, the more smooth and gradual absorption of energy and the less impact to the vehicle's occupants. In other words, the larger stopping distance allows more deformation into the buffer system until the vehicle stops. One way to allow for greater stopping distance is to increase the size of the buffer. The significance of this can be clearly observed by Equation (1), which shows the average deceleration $(a)$ is inversely proportional to the stopping distance $(h)$.

$$
a=v^{2} / h
$$

where, $v$ is the velocity of vehicle. The increase in buffer length can be achieved by the addition of more cells in the buffer. However, the larger length of the buffer means that many cells need to be used, which may increase the fabrication cost, setup and installation time. An alternative to adding more cells to increase the length is increasing the size of the individual cells, i.e. increasing the diameter of the cells. Increasing the size of the individual buffer cells could potentially lead to several significant benefits. These include more compact (shorter) buffer, greater ease of assembly of the cells and allow much greater accessibility. This is particularly true for the buffers with higher speed zones, where more cells are needed. The cost associated with material and fabrication will be dramatically reduced as less number of cells is required.

\section{Materials and Method}

\subsection{Modified Cell Design}

This paper focuses on design of modified cell geometry over the previous cell design by Zivkovic and Winfield [30], with an aim to (1) reduce the number of cells, (2) increase energy absorption capacity and (3) reduce manufacturing and handling cost. The previous cell design contains $114.3 \mathrm{~mm}$ outside diameter with a wall thickness of $4.5 \mathrm{~mm}$. If four of these cells are attached in series to form a buffer, it will give a width of $457.2 \mathrm{~mm}$. Figure 2 shows the geometric definition of a cell. It would be preferable to replace these four cells with either two or 


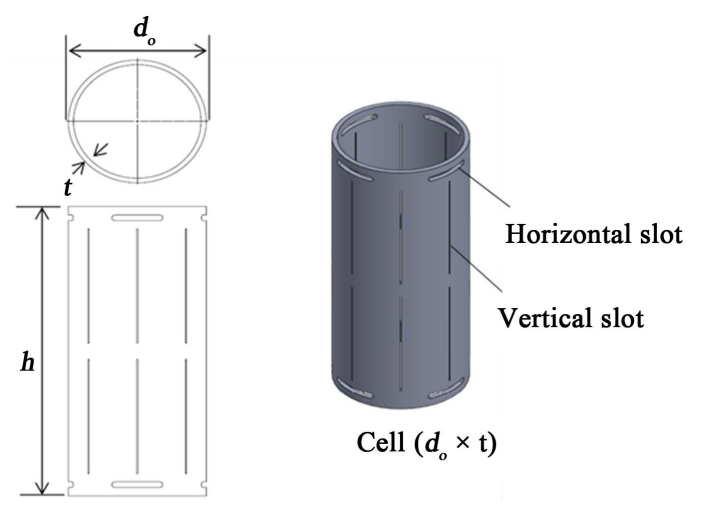

Figure 2. Geometric definition of a buffer cell.

three relatively larger cells, which would result in the overall width of the buffer remaining the same or similar. Note that the width of a buffer is defined as the product of the number of cells and the outer diameter of a cell.

With this aim, three different cell geometries with larger outer diameters (Cells A, B, and C) are considered in this study as shown in Table 1. Outer diameter of Cells B and C is the same except for thickness. For instance, three-cell assembly made with Cell A design would give a width of $495.3 \mathrm{~mm}$, while two-cell assembly made with Cell B or C design would give a width of $438.2 \mathrm{~mm}$. The width of both assemblies is close to that of the previous design (of foul-cell assembly) and would be considered acceptable size.

As can be seen in Figure 2, in the modified cell design, the location of horizontal slots and thus the length of vertical slots were modified to allow more stiffness at the fixation points between the cells. It must be noted that although it is likely that other geometry of cell would be preferred for the buffer, only geometries available from the local supplier were considered, for the sake of the justification of the proposed design modification. The performance of these three geometries was tested using both finite element simulations and experiments to find which cell geometry provides a cost effective and high energy absorbing buffer system for high speed zones.

\subsection{Finite Element Modelling}

A nonlinear quasi-static (i.e. implicit) simulation using finite element (FE) method was conducted in order to gain a greater understanding of how the individual cells deform and how much force would be needed to initiate the deformation. This, in turn, enabled to estimate the energy absorption or workdone capacity of the cells under the given impact load. For the sake of simplicity and being computationally effective, finite element analysis was initially applied on single cells. The simulation setup was designed in such a way that it could be replicated by a real experiment for future comparison. Figure 3(a) shows the finite element model of a cell.

The FE model consisted of a cell placed between a top and a bottom plate, the bottom plate was fixed while the top plate was allowed to move only in the vertical direction. The top plate was assigned a vertical displacement that would force the cell to be compressed laterally. This would replicate a push plate attached to a hydraulic cylinder during real life experimentation (see details in "Experiments" section). A reaction force probe was applied to the bottom surface of the top plate to estimate the force against the displacement of the cell.

ANSYS, a commercially available finite element code [31], was applied to solve the contact problem between the cell and the top and bottom plates. As the surface model of the cell was imported into the ANSYS platform, 4-node shell elements were used to mesh the simulation model. They were found to allow large strain deformation. Solid elements were also studied. However, both solid and shell elements had insignificant influence on the deformation. Interestingly, shell elements were shown to reduce the computational time, as opposed to 8-node solid elements. A mesh convergence study was performed to investigate the effect of mesh size. Mesh size was varied and after simulation, the change in deformation and von Mises stress of the cell were observed. Fine meshing was considered at the critical locations such as slots while course meshing was used at other areas. An optimum mesh size was found, for which, the percentage of error was $1 \%-5 \%$, which was considered an acceptable limit for engineering analysis. Mesh convergence study was repeated for all cell geometries as well.

The material of the cells studied was mild steel. The data for multi-linear isotropic hardening stress-strain curve for the material was obtained from experimental study [30]. Figure 3(b) shows the stress-strain data curve 


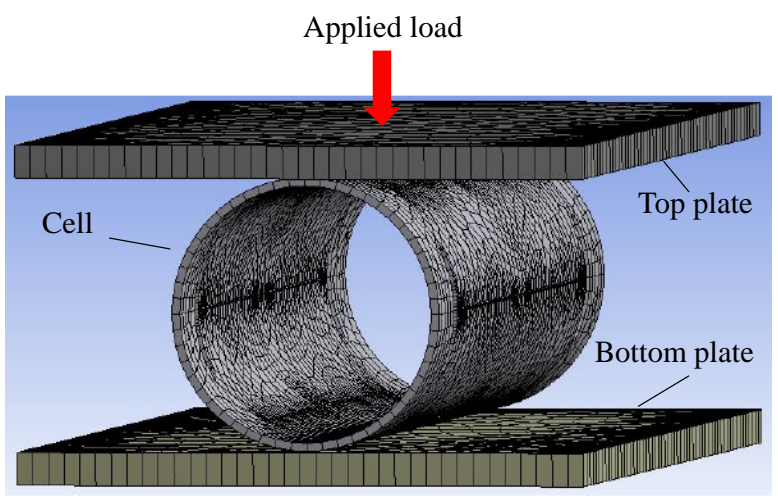

(a)

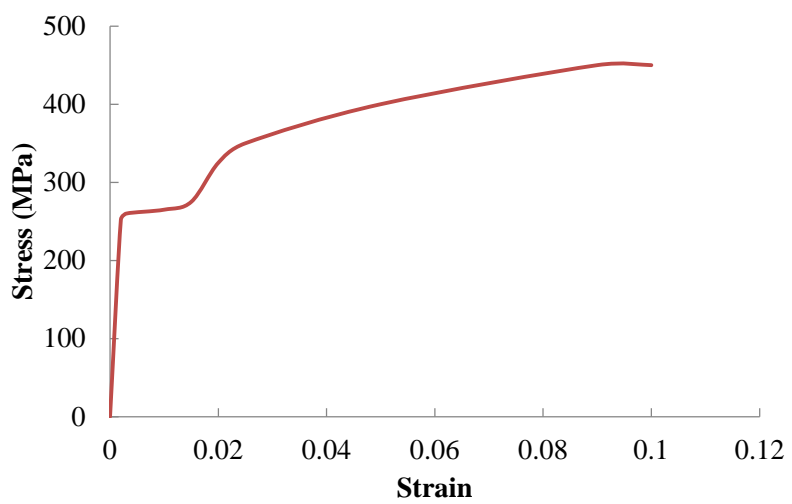

(b)

Figure 3. (a) FE model of a cell (b) stress-strain data of cell material (mild steel) used in FE analysis.

Table 1. Geometric dimension of the cells studied.

\begin{tabular}{cccc}
\hline Cell geometry & Outer diameter, $d_{o}(\mathrm{~mm})$ & Wall thickness, $t(\mathrm{~mm})$ & Cell height, $h(\mathrm{~mm})$ \\
\hline Cell A & 165.1 & 5.0 & 510 \\
Cell B & 219.1 & 6.4 & 510 \\
Cell C & 219.1 & 8.2 & 510 \\
\hline
\end{tabular}

for mild steel, which is feed into the material library of the software during simulation. The effect of frictional contact between the cell and the top and bottom plates was studied. It was found that that friction had a negligible effect on the deformation pattern and magnitude of the cell. Hence, the contact was assigned as frictionless throughout simulation. This was also found to reduce computational time.

By following the same loading and boundary conditions used for the single cell geometry, the simulation for two-cell and four-cell assembly was performed to investigate the deformation behaviour of a buffer-like system comprising a series of cells. In this case, two cells or four cells were placed in between the top and the bottom plates in the simulation environment. The spot weld contact was assumed at connection between two cells to represent the actual bolt joint connection of the cells. Initial simulation results showed that the magnitude of deformation and energy absorption of single cell geometry had a linear relationship with that of two-cell and fourcell assemblies and for the limitation of space, the modelling details and the simulation results for two-cell and four-cell are not presented here. Therefore, the result and analysis presented in the paper were based on the deformation of a single cell. After each simulation, load and displacement data were estimated. This was used to calculate the amount of workdone and energy absorbed by the cells. The results were plotted and analysed to design an optimum buffer system. 


\subsection{Experiments}

Experiments involving lateral compression were conducted in order to investigate the deformation of the individual cells. The aim was to validate the quasi-static FEA simulations. The tests involved the deformation of a cell located between two plates at top and bottom. The bottom plate was fixed and the top plate (push plate) was attached to a 20-tone hydraulic cylinder so that the cell was deformed in a controlled way that would enable the reaction force acting on the top plate to be recorded for each of the desired displacements. Figure 4 shows the experimental setup for the cell deformation. At a certain interval of displacement, applied loads and displacements were measured by using a hydraulic pressure gauge and a linear encoder, respectively. During the tests, the deformation of the cell was allowed to $75 \%$ of its total deformation capacity. Note that the hydraulic pressure gauge was calibrated with a commercially available standard load cell to justify the accuracy of the load readings. Load-displacement and energy absorption plots were created for each test and used to compare with the corresponding plots from the FE simulations.

\subsection{Buffer Designs}

Based on the experimental and simulation results and data obtained for individual cell geometries, potential buffers were designed. The main focus is to determine the amount of energy that can be absorbed by the different cell. Energy absorption data for the individual cells obtained from the experiments were used to design the size of the buffer system as they were assumed to be the most reliable. Note that the design of the buffer presented in this study is assumed for the frontal collision; in other words, the front of an errant vehicle will hit front of the buffer.

The idea is that by knowing the amount of kinetic energy that a vehicle will have in any speed zone and the amount of the energy a cell can absorb, one can determine the number of cells that will be arranged in series to form the buffer system that will be able to absorb the desired amount of the energy due to the impact. It is reported that major of road crashes involve the front of the car hitting other objects such as the front of another cars or fixed roadside objects [32]. Therefore, in this study, the buffer system is designed assuming that the energy absorption or the deformation of the cells would be due to the frontal impact between a car and a fixed object.

It is assumed that during an impact, half of the total kinetic energy of the vehicle is absorbed by the vehicle itself. Hence, the aim of the buffer system is to be able to absorb the rest half of total kinetic energy through the deformation of the individual cells. Assume that a vehicle of mass, $m_{\text {vehicle }}$ travelling at a velocity of $v$ hits a fixed object. The total kinetic energy of the vehicle can be estimated as:

$$
K . E_{\text {total }}=\frac{1}{2} m_{\text {vehicle }} * v^{2} .
$$

Hence, the kinetic energy to be absorbed by the buffer system can be calculated as:

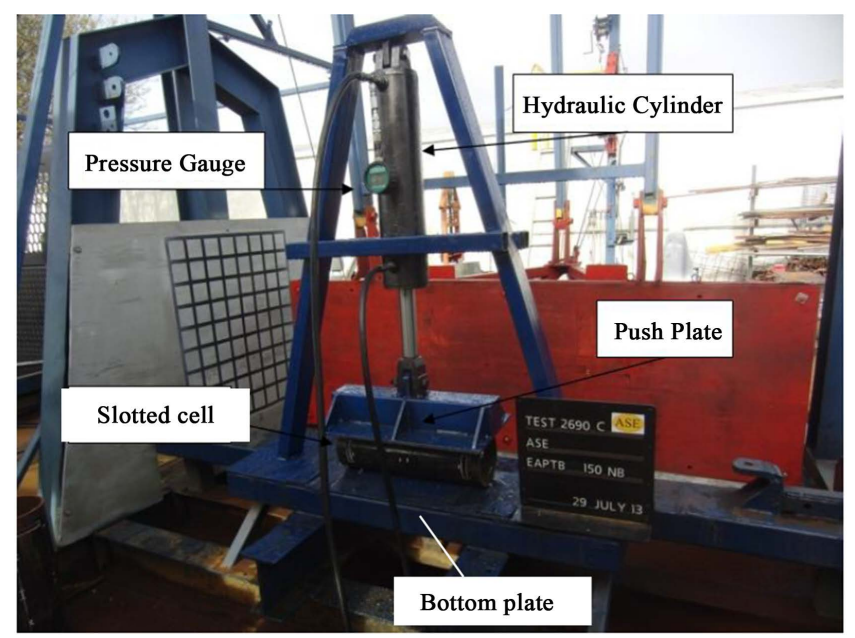

Figure 4. Experimental setup for the cell deformation. 


$$
K ._{\text {buffer }}=\frac{1}{2} K . E_{\text {total }} .
$$

Let's assume that the buffer system comprises a series of rows of the cells attached to together. The kinetic energy is absorbed through the continuous deformation of the cells. Figure 5 shows an example arrangement of cells in a buffer design. If the energy absorption capacity of an individual cell at its 75\% deformation, K.E. cell and the number of cells in a row, $m$, are known, the number of rows, $N$ that will form the buffer system can be estimated as:

$$
N=\frac{K \cdot E_{\text {buffer }}}{K \cdot E_{\cdot_{\text {cell }}}} * m .
$$

Accordingly, for the given cell geometry (i.e. outer diameter of a cell, $d_{o}$ ), the size of the buffer system can be estimated as:

The width of the buffer, $W=($ number of cells in a row $) *($ outer diameter of a cell $)=m * d_{o}$

The length of the buffer, $L=$ (number of rows in a buffer $) *($ outer diameter of a cell $)=N * d_{o}$

This way, one can determine the size of the buffer system that will be able to absorb the impact energy of an out-of-control vehicle travelling at any speed.

\section{Results and Discussion}

\subsection{Comparison between Simulation and Experiment}

Figure 6 shows a comparison of cell deformation patterns obtained from experiment and simulation. Both experiment and simulation display exactly the same trend of the deformation until the cell reaches its maximum deformation level. The cell undergoes both elastic and plastic deformations, except for a broken weld spot observed at the contact between the cell and the bottom plate. Damage at the weld can be due to improper welding or unexpected lateral movement of the cell under experimental loading. Overall, the results for a single cell justify the accuracy of the current FE model, thus indicating that the model would be able to reasonably estimate the accurate deformation of a buffer system consisting of a series of individual cells.

Figure 7 illustrates a comparison of load-displacement and energy absorption patterns obtained from experiment and simulation for all three cells. The amount of energy absorption by the cell or work done by the top

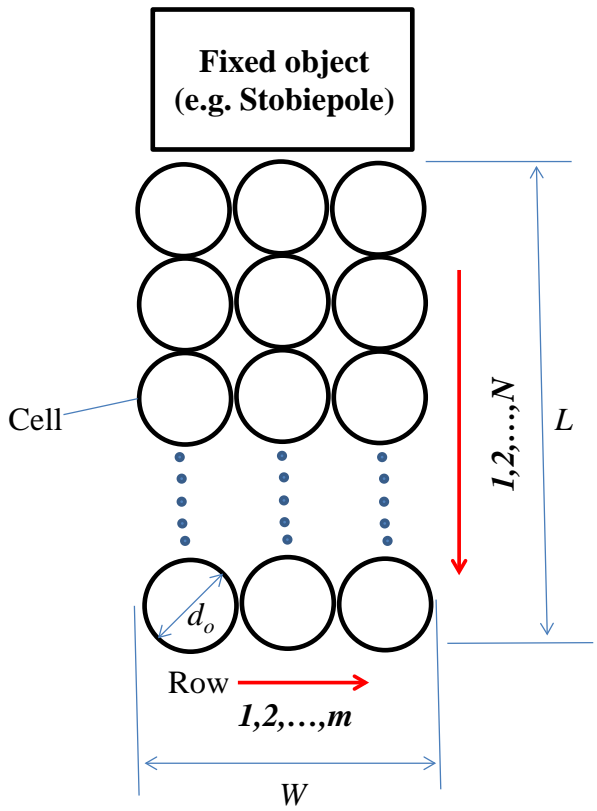

Figure 5. Illustration of parameters of a potential buffer design. 


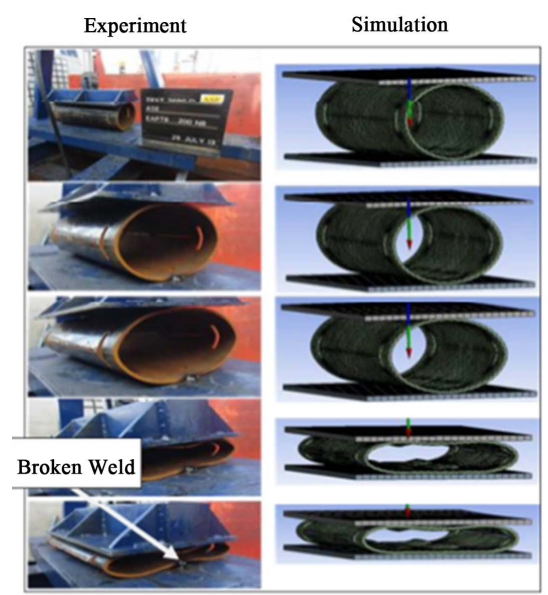

Figure 6. Comparison of simulated and experimental deformation of an individual cell.
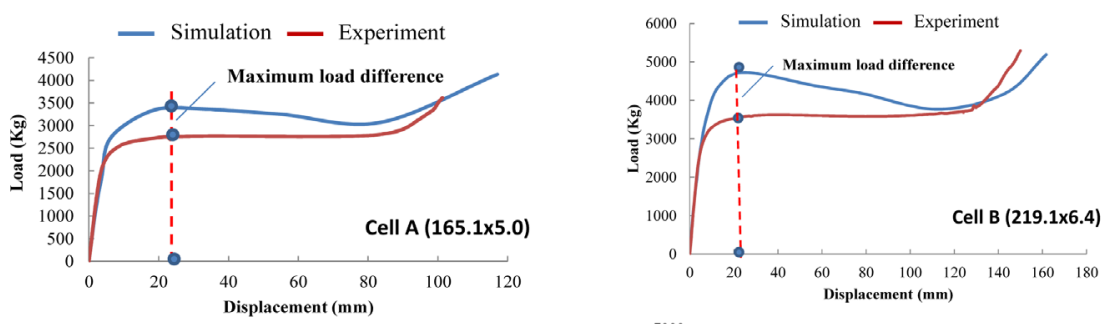

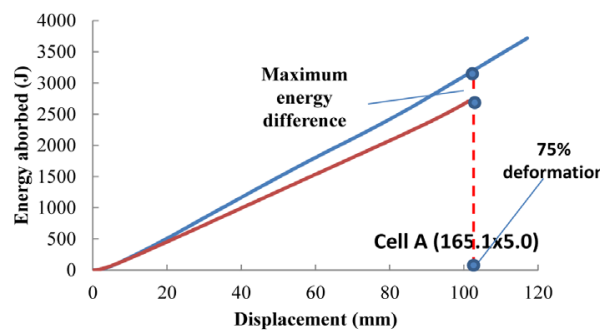

(a)

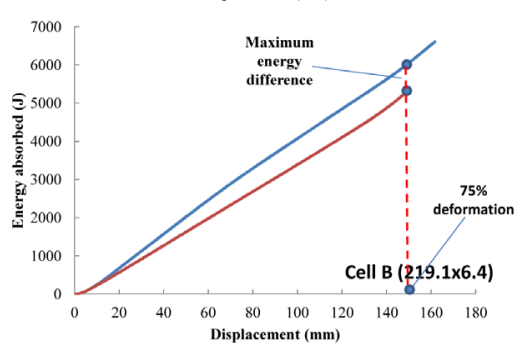

(b)
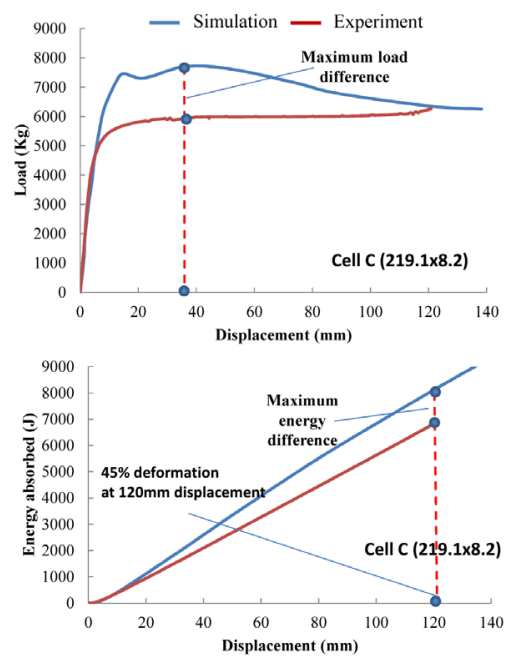

(c)

Figure 7. Load-displacement(top) and energy absorption (bottom) results for (a) Cell A, (b) Cell B, (c) Cell C. 
(push) plate was estimated by integrating area under the load-displacement curve. The energy was estimated and plotted until 75\% of the cell's maximum deformation level. Results show that the overall trend of the load-displacement and energy absorption is relatively similar. At early stage, the magnitude of experimental and simulation load to deform the cell is almost same. However, after initial elastic deformation of about 5 - $10 \mathrm{~mm}$, simulation load is higher than experimental, and this pretty much remains constant until the cell reaches its maximum deformation. On the other hand, the cumulative energy absorption capacity increases linearly with the deformation of the cell.

For instance, as can be seen in Figure 7(a), for Cell A, the maximum error between experimental and simulated load was found to be $17.70 \%$ at about $22 \mathrm{~mm}$ displacement. The maximum error in energy absorption obtained from experiment and simulation was estimated to be $22.97 \%$ at $75 \%$ of the cell's maximum deformation (at about $113 \mathrm{~mm}$ displacement). As shown in Figure 7(b), for Cell B, the maximum error between experimental and simulated load was found to be $24.35 \%$ at about $24.75 \mathrm{~mm}$ displacement. The maximum error in energy absorption obtained from experiment and simulation was estimated to be $11.4 \%$ at $75 \%$ of the cell's maximum deformation (at about $151 \mathrm{~mm}$ displacement). For Cell C, the maximum error between experimental and simulated load was found to be $30 \%$ at about $36.11 \mathrm{~mm}$ displacement, as can be seen in Figure 7(c). The maximum error in energy absorption obtained from experiment and simulation was estimated to be $15.72 \%$ at $45 \%$ of the cell's maximum deformation, as the simulation was stopped at about $120 \mathrm{~mm}$ displacement.

The difference in the cell strength obtained from experiment and simulation is believed to be the results of pre-stressed state of the cell used in experiments caused by the manufacturing processes. Material properties assigned to the cell in the FE simulation model may not exactly match with the actual mild steel properties of the cell itself. In addition, the contact between the cell and the top and bottom plates was assumed to be an ideal weld joint in simulation. However, a broken weld spot was observed during experiments (see Figure 6).

Figure 8 shows the comparison of load-displacement and energy-displacement among three cell geometries. It can be seen that Cell $\mathrm{C}$ has the highest strength among all. This means that one needs a larger amount of load to deform the cell so that the energy is absorbed. This further indicates that Cell $\mathrm{C}$ is too hard and rigid. This is generally not desired in an energy absorbing buffer system as the main objective of a buffer is to absorb the impact energy through deformation of the cells as quickly as possible so that a smooth and comfortable ride down deceleration is realized by the vehicle's occupant. On the other hand, Cell A and Cell B show almost the similar level of deformation and indicate more flexibility and are ready to absorb the energy. Therefore, in this study, we use Cell A and Cell B as base cell geometries to design potential buffer systems, which are discussed in the following section.

\subsection{Buffer Configurations}

\subsubsection{Buffer Designs for $80 \mathrm{~km} / \mathrm{h}$ Speed}

We assume that the mass of a vehicle, $m_{\text {vehicle }}$ of $1600 \mathrm{~kg}$ [30], travelling at a speed, $v$ of $80 \mathrm{~km} / \mathrm{h}$. Using Equation (2) and Equation (3), total kinetic energy of the vehicle is $395 \mathrm{~kJ}$, and the energy to be absorbed by the buf-

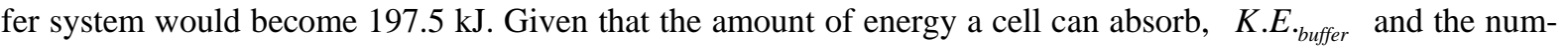
ber of cells in a row, $m$, the number of rows, $N$ and the number of cells, $m_{\text {total }}$ that will form the size of the buffer can be estimated using Equations (4)-(6). The main aim is to design possible buffer sizes that will be relatively shorter in length as compared to the commercially available buffer systems, and be able to use in different roadways to absorb the required energy for the vehicle travelling at $80 \mathrm{~km} / \mathrm{h}$,.

Table 2 summarizes the result of potential buffer designs for $80 \mathrm{~km} / \mathrm{h}$ speed zone. For the given cell geometry, we vary the number of cells in a row to find different size of the buffer. Figure 9(a) shows the configuration of the designed buffers. Figure 9(b) shows load-displacement and energy absorption of the buffers at $75 \%$ of their maximum capacity, assuming that the buffer will follow the same deformation of a single cell. The deformation and energy absorption of the buffer was estimated by performing an extrapolation on experimental deformation data for a single cell. It is seen that the increase in the cell size and the number of cells in a row increases the width and decreases the length of the buffer. This similarly influences the load-displacement and energy absorption data curves. For example, as can be seen in Figure 9, the buffers with Cell A, $m=4$ and Cell B, $m=3$ show almost the same energy absorption capacity, but the buffer with larger cell, Cell B, $m=3$ contains significantly less number of cells. This will potentially reduce the cost associated with the materials and manufacturing of the cells. This further indicates that the buffer with relatively large cells is cost effective, while it withstands high impact energy. 


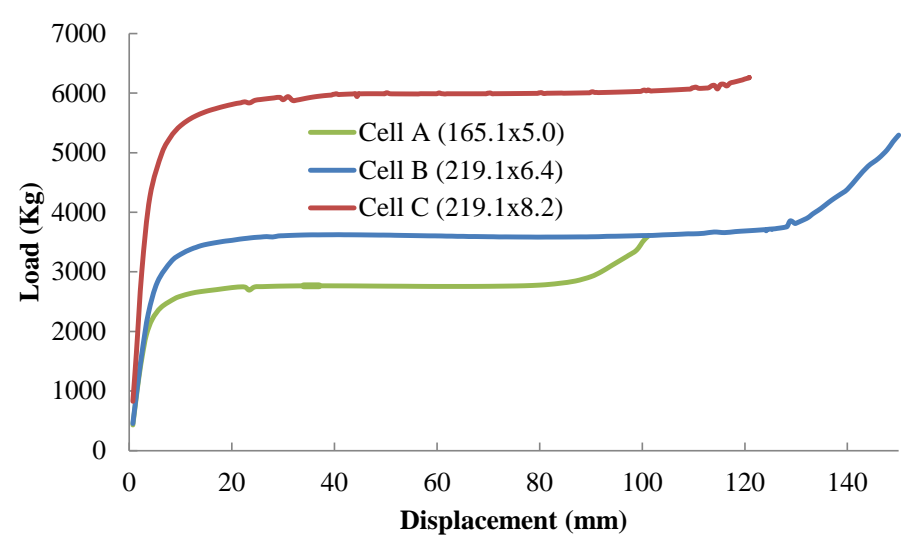

(a)

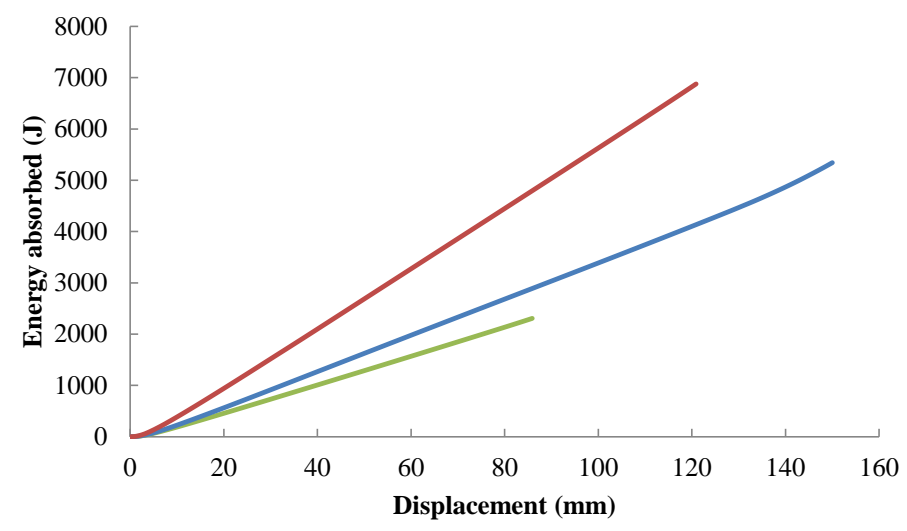

(b)

Figure 8. Comparison of (a) load-displacement, (b) energy absorption results for Cells A, B, and C.

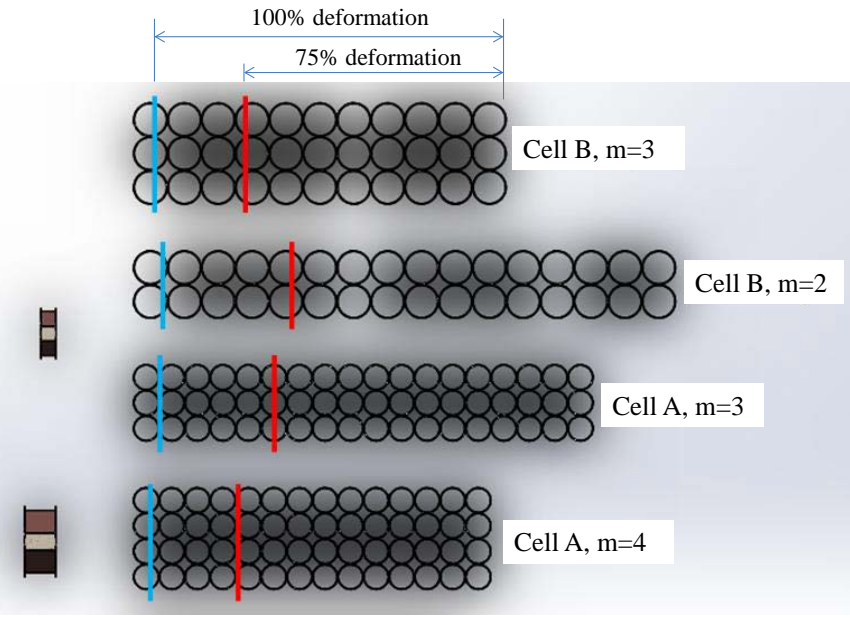

(a)
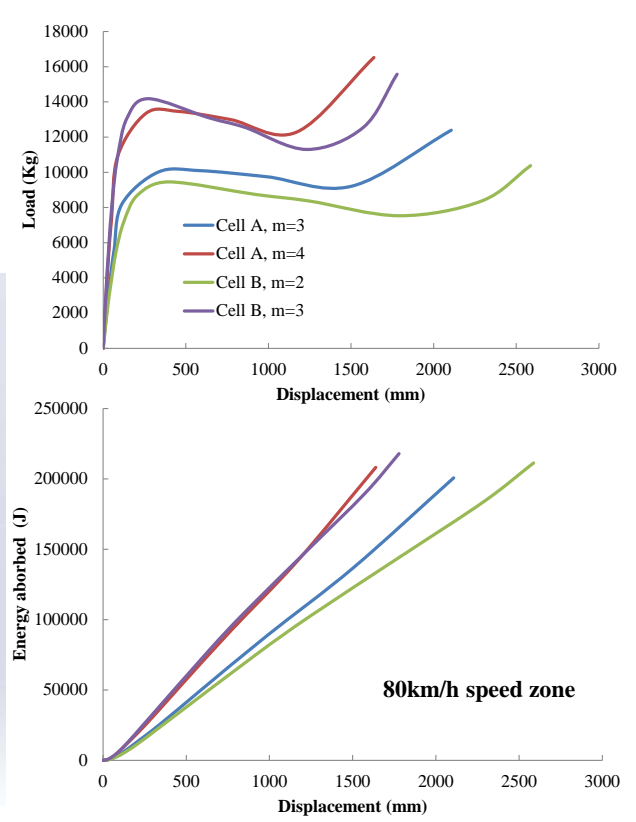

(b)

Figure 9. (a) Buffer designs, (b) load and energy absorption results for corresponding designs for $80 \mathrm{~km} / \mathrm{h}$ speed. 
Table 2. Buffer designs for $80 \mathrm{~km} / \mathrm{h}$ speed.

\begin{tabular}{ccccccc}
\hline Buffer design & $\begin{array}{c}\text { Energy absorbed by } \\
\text { buffer, } K . \text { E.buffer }(\mathrm{kJ})\end{array}$ & $\begin{array}{c}\text { Energy absorbed } \\
\text { by buffer, } K . E_{\text {cell }}(\mathrm{kJ})\end{array}$ & $\begin{array}{c}\text { No of } \\
\text { rows, } N\end{array}$ & $\begin{array}{c}\text { No of cells in } \\
\text { a buffer, } m_{\text {total }}\end{array}$ & $\begin{array}{c}\text { Width of buffer, } \\
W(\mathrm{~mm})\end{array}$ & $\begin{array}{c}\text { Length of } \\
\text { buffer, } L(\mathrm{~mm})\end{array}$ \\
\hline Cell A, $m=3$ & 197.5 & 3.7 & 18 & 54 & 495.3 & 2971 \\
Cell A, $m=4$ & 197.5 & 3.7 & 14 & 56 & 660.4 & 2311 \\
Cell B, $m=2$ & 197.5 & 6.25 & 16 & 32 & 438.2 & 3505 \\
Cell B, $m=3$ & 197.5 & 6.25 & 11 & 33 & 657.3 & 2401 \\
\hline
\end{tabular}

For all the buffer designs, the width and the length were found to be quite less than $1000 \mathrm{~mm}$ and $4000 \mathrm{~mm}$, respectively, which are acceptable. The sizes of the buffers were significantly smaller than the available buffer sizes of Quad Guard, e.g. $4910 \mathrm{~mm}$ - $8290 \mathrm{~mm}$ in length for speed zone of $80 \mathrm{~km} / \mathrm{h}$ [23].

\subsubsection{Buffer Designs for $100 \mathrm{~km} / \mathrm{h}$ Speed}

Following the same procedure for $80 \mathrm{~km} / \mathrm{h}$ speed as described in earlier section, potential buffers for $100 \mathrm{~km} / \mathrm{h}$ speed zone have been designed. Table 3 summarizes the results of buffer design for $100 \mathrm{~km} / \mathrm{h}$. The number of cells in a row (m) was varied to find the acceptable sizes of the buffers that will absorb the required impact energy. Figure 10(a) shows configurations of potential buffers. Figure 10(b) illustrates the extrapolated loaddisplacement and energy absorption of the buffers at $75 \%$ of their maximum capacity.

It can be observed from figures that the arrangement of the cells influences the size, deformation, and energy absorption capacity of the buffers in a similar fashion of those for $80 \mathrm{~km} / \mathrm{h}$ speed. Larger cells with a large number of cells in a row increase energy absorption and decrease the size of the buffers. This also holds the benefit of reduced number of cells in a buffer, which results in significant cost reduction. For all buffer configurations for $100 \mathrm{~km} / \mathrm{h}$, the width and length of the buffers are below $1000 \mathrm{~mm}$ and $6000 \mathrm{~mm}$, respectively. The sizes are lower than those of commercially available buffers for $100 \mathrm{~km} / \mathrm{h}$, e.g. Absorb360 Crash Cushion of 7750 - $9700 \mathrm{~mm}$ in length [24]. Therefore, depending on the space and environment of roadways, these proposed buffer designs can potentially be used to minimize the severity of the crash of high speed vehicles hitting the fixed objects.

There are a number of limitations that may hinder the performance of the FE model, and hence, impact the results and analysis. In this study, a quasi-static single cell deformation was tested using both simulation and experiment. However, dynamic experimental crash testing is required to evaluate and justify the deformation and energy absorption capacity of the buffers. In accordance with Manual for Assessing Safety Hardware proposed in [33], occupant risk value and occupant ride-down acceleration ( $g$-force) would be estimated to assess the potential injury impact onto vehicle occupants. Uniform deformation of the cells under the impact is important to maximize the energy absorption. The slots on the cells provide the flexibility and enable the deformation. Therefore, size, location and orientation of the circular and vertical slots on the cells may need to be optimized so that the required energy is absorbed by the buffers with a comfortable stopping distance of the vehicle after the impact. This will be addressed in our future work.

\section{Concluding Remarks}

This paper studied design and analysis of cost-effective and high energy absorbing buffer systems for high speed roadways. Deformation and energy absorption capacity of the single cell with different diameters and thicknesses were evaluated using quasi-static tests by finite element simulation and experimental technique. Simulation results matched closely with experimental ones with relatively small errors, suggesting that the FE model presented in this paper was able to accurately estimate the deformation of cells under the quasi-static loading. Based on experimental results of single cells, a number of potential buffer systems were designed for $80 \mathrm{~km} / \mathrm{h}$ and $100 \mathrm{~km} / \mathrm{h}$ speed roadways. Results indicate that the buffers with larger diameter cells, e.g. Cell B, $m=3$, Cell A, $m=5$ are favorable to be used in high speed zones as they reduce the overall size of buffers and contain less number of cells, while being able to absorb the required amount of impact energy at the given speed. All the buffer designs are relatively shorter than commercially available buffers used in roadways. Consequently, they will potentially result in a reduced cost associated with materials, fabrication, installation and maintenance. In 


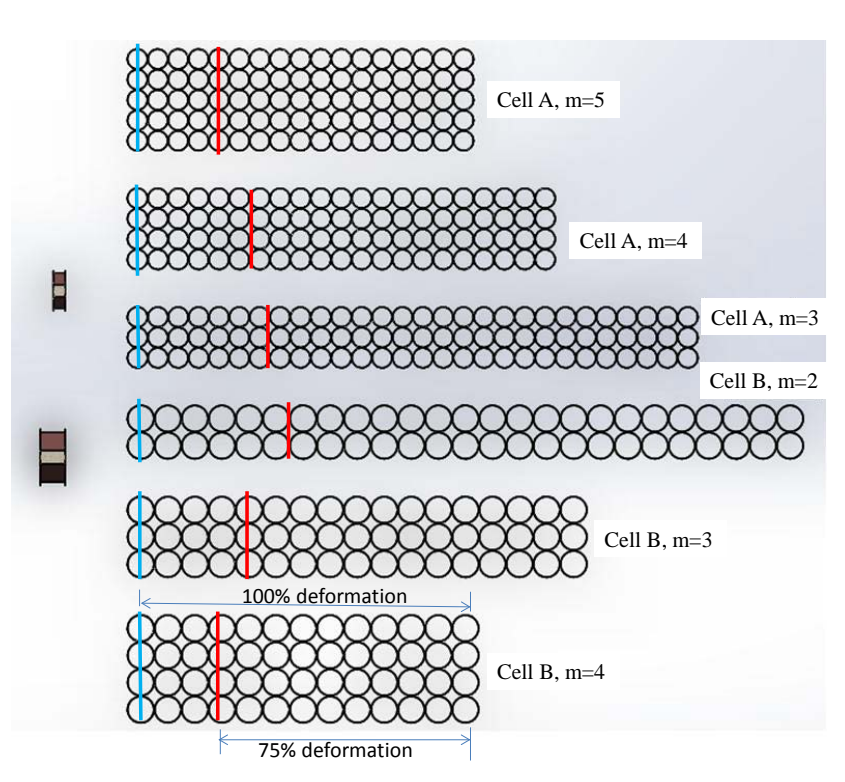

(a)

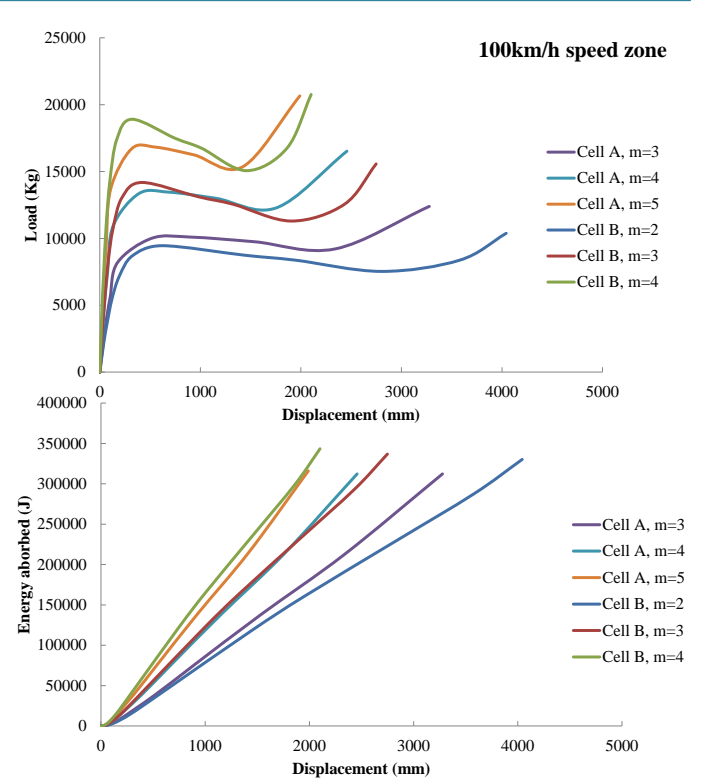

(b)

Figure 10. (a) Buffer designs, (b) load and energy absorption results for corresponding designs for $100 \mathrm{~km} / \mathrm{h}$ speed.

Table 3. Buffer designs for $100 \mathrm{~km} / \mathrm{h}$ speed.

\begin{tabular}{|c|c|c|c|c|c|c|}
\hline Buffer design & $\begin{array}{c}\text { Energy absorbed } \\
\text { by buffer, K. E. buffer }(\mathrm{kJ})\end{array}$ & $\begin{array}{c}\text { Energy absorbed } \\
\text { by buffer, } K . E_{\text {.cell }}(\mathrm{kJ})\end{array}$ & $\begin{array}{l}\text { No of } \\
\text { rows, } N\end{array}$ & $\begin{array}{l}\text { No of cells in } \\
\text { a buffer, } m_{\text {total }}\end{array}$ & $\begin{array}{c}\text { Width of } \\
\text { buffer, } W(\mathrm{~mm})\end{array}$ & $\begin{array}{c}\text { Length of } \\
\text { buffer, } L(\mathrm{~mm})\end{array}$ \\
\hline Cell A, $m=3$ & 308.6 & 3.7 & 28 & 84 & 495.3 & 4623 \\
\hline Cell A, $m=4$ & 308.6 & 3.7 & 21 & 84 & 660.4 & 3467 \\
\hline Cell A, $m=5$ & 308.6 & 3.7 & 17 & 85 & 825.5 & 2807 \\
\hline Cell B, $m=2$ & 308.6 & 6.25 & 25 & 50 & 438.2 & 3505 \\
\hline Cell B, $m=3$ & 308.6 & 6.25 & 17 & 51 & 657.3 & 2401 \\
\hline Cell B, $m=4$ & 308.6 & 6.25 & 13 & 52 & 876.4 & 3725 \\
\hline
\end{tabular}

addition, depending on the nature and available space of the roadways, the designed buffers can potentially be installed in a space limited hazardous road environment to reduce the vehicle crash with the fixed objects.

\section{References}

[1] BITRE (2000) Cost of Road Crashes in Australia. Bureau of Infrastructure, Transport and Regional Economics, Canbera, Australia.

[2] BITRE (2011) Cost of Road Crashes in Australia. Bureau of Infrastructure, Transport and Regional Economics, Canbera, Australia.

[3] IIHS (2011) Fatality Facts: Collisions with Fixed Objects and Animals. Insurance Institute for Highway Safety.

[4] Berg, A. and Ahlgrimm, J. (2010) Tree Impacts—Still One of the Most Important Focal Points of Road Deaths. Berichte Bundesanst, Fuer Strassenwes, Unterreihe Fahrzeugtechnik, No. 77.

[5] Zivkovic G. (2008) Energy Absorbing Pole/Tree Buffer. Automotive Safety Engineering Pty Ltd., Adelaide, Australia.

[6] Lake, G. (2010) Local Government and Road Safety. Journal of the Australasian College of Road Safety, 21, 17-19.

[7] Wang, Y.G., Chen, K.M., Ci, Y.S. and Hu, L.W. (2011) Safety Performance Audit for Roadside and Median Barriers Using Freeway Crash Records: Case Study in Jiangxi, China. Scientia Iranica, 18, 1222-1230. http://dx.doi.org/10.1016/j.scient.2011.11.020

[8] Lu, G. and Yu, T.X. (2003) Energy Absorption of Structures and Materials. Woodhead Publishing Limited, Cambridge, UK. 
[9] Njuguna, J. (2011) The Application of Energy Absorbing Structures on Side Impact Protection Systems. International Journal of Computer Applications in Technology, 40, 208-207. http://dx.doi.org/10.1504/IJCAT.2011.041657

[10] Baker, B.C., Nolan, J.M., O’Neill, B. and Genetos, A.P. (2008) Crash Compatibility between Cars and Light Trucks: Benefits of Lowering Front-End Energy-Absorbing Structure in SUVs and Pickups. Accident Analysis \& Prevention, 40, 116-125. http://dx.doi.org/10.1016/j.aap.2007.04.008

[11] Tay, Y.Y., Lim, C.S. and Lankarani, H.M. (2014) A Finite Element Analysis of High-Energy Absorption Cellular Materials in Enhancing Passive Safety of Road Vehicles in Side-Impact Accidents. International Journal of Crashworthiness, 19, 288-300. http://dx.doi.org/10.1080/13588265.2014.893789

[12] Xie, S., Liang, X. and Zhou, H. (2015) Design and Analysis of a Composite Energy-Absorbing Structure for Use on Railway Vehicles. Proceedings of the Institution of Mechanical Engineers, Part F: Journal of Rail and Rapid Transit, 0954409714566058.

[13] Otte, D., Sferco, R., Schaefer, R., Eis, V., Thomas, P. and Welsh, R. (2009) Assessment of Injury Severity of Nearside Occupants in Pole Impacts to Side of Passenger Cars in European Traffic Accidents-Analysis of German and UK In-Depth Data.

[14] Lacy, K., Srinivasan, R., Zegeer, C., Pfefer, R., Neuman, T., Slack, K. and Hardy, K. (2004) NCHRP Report 500: Guidance for Implementation of the AASHTO Strategic Highway Safety Plan-Volume 8: A Guide for Reducing Collisions Involving Utility Poles. Transportation Research Board of the National Academies, Washington DC.

[15] Elvik, R. (1995) The Safety Value of Guardrails and Crash Cushions: A Meta-Analysis of Evidence from Evaluation Studies. Accident Analysis \& Prevention, 27, 523-549. http://dx.doi.org/10.1016/0001-4575(95)00003-I

[16] Pang, T.Y. and Tristian, H. (2014) Experimental and Finite Element Nonlinear Dynamics Analysis of Formula SAE Impact Attenuator. In: Jazar, R.N. and Dai, L., Eds., Nonlinear Approaches in Engineering Applications 2, Springer, New York, 213-229. http://dx.doi.org/10.1007/978-1-4614-6877-6_7

[17] Thiyahuddin, M.I., Gu, Y.T., Thambiratnam, D.P. and Thilakarathna, H.M. (2014) Impact and Energy Absorption of Portable Water-Filled Road Safety Barrier System Fitted with Foam. International Journal of Impact Engineering, 72, 26-39. http://dx.doi.org/10.1016/j.ijimpeng.2014.04.008

[18] Roberts, M. (2014) Development of a Finite Element Model for Predicting the Impact Energy Absorbing Performance of a Composite Structure. Masters Theses Project Reports, California Polytechnic State University, San Luis Obispo, CA, USA.

[19] Boria, S. and Pettinari, S. (2014) Mathematical Design of Electric Vehicle Impact Attenuators: Metallic vs Composite Material. Composite Structures, 115, 51-59. http://dx.doi.org/10.1016/j.compstruct.2014.04.010

[20] Wilson, A.H. (1979) Roadside Tree/Pole Crash Barrier Field Test. Jet Propulsion Laboratory, California Institute of Technology, Pasadena.

[21] Krage, W.G. and Denman, O.S. (1988) Collapsible Highway Barrier. US4784515 A.

[22] Nabors, D.T. and Hossain, M. (1998) Development of a Low-Cost Crash Cushion Using Recycled Automobile Tires.

[23] Michalec, C.R. (2005) Development of an Optimal Impact Energy Absorber for Highway Crash Cushions. Texas A\&M University, College Station.

[24] Whitehead, M. (2014) Road Safety Barrier Systems, End Treatments and Other Related Road Safety Devices. Department of Transport and Main Roads, Queensland.

[25] Saferoads (2015) Rubber Speed Crash Cushion. Saferoads, Australia.

[26] Australian Construction Product (2015) Universal TAU-II Crash Cushion. Australian Construction Product (ACP), Australia.

[27] Bolyan (2015) Quadguard Cushion System. Bolyah Group, Australia.

[28] Road Management Solutions (2015) Absorb 360 Crash Cushion. Road Management Solutions, Australia.

[29] Zivkovic, G. and Day, J. (2012) Safety Barrier Product Information Report. Automotive Safety Engineering Pty Ltd., Adelaide.

[30] Zivkovic, G. and Winfield, M. (2010) A Study into the Lateral Compression of a 115 mm Diameter Steel Tube. Automotive Safety Engineering Pty Ltd., Adelaide.

[31] Ansys (2015) Finite Element Analysis Tool. Ansys Inc. http://www.ansys.com

[32] Fildes, B.N., Lane, J.C., Lenard, J. and Vulcan, A.P. (1991) Passenger Cars and Occupant Injury. Monash University Accident Research Centre.

[33] Sicking, D., Mak, K., Rohde, J. and Reid, J. (2009) Manual for Assessing Safety Hardware. American Association of State Highway Transportation Officials, Washington DC. 